\title{
Intensitas Kepercayaan Konsumen , Citra Merek Dan Kepuasan Konsumen Terhadap Loyalitas Customer Chatime Di Mall Ciputra Semarang.
}

\author{
Fina Nailul Izzah ${ }^{1}$ \\ finanailul5@gmail.com \\ Alfi Munfiah ${ }^{2}$ \\ alfimunfiah29@gmail.com \\ Sita Tri Apriliani ${ }^{3}$ \\ sitaapriliana450@gmail.com \\ Vina Puspita Risdiyanti ${ }^{4}$ \\ vinapuspitar@gmail.com \\ Ratih Pratiwi ${ }^{5}$ \\ rara@unwahas.ac.id
}

Fakultas Ekonomi Universitas Wahid Hasyim Semarang

\begin{abstract}
:
This study was conducted in Mall Ciputra Semarang. The purpose of this study is to determine Itensitas consumer trust, brand image and customer satisfaction on loyalty customer chatime in the Mall Ciputra. This research includes the type of descriptive quantitative research where that is produced in the form of numbers analysis and statistics. The method used in research to obtain data that is questionnaire method. The population in this article are all customers chatime domiciled in the City of Semarang. Sampling technique used in this research is the formula of isaac and michael, where the technique of determining the sample used to calculate the sample population is not known for sure. The respondent in this article are the 99 people. Data collection was done through questionnaires with measurement scale likert 1 s/d 5 and the data obtained were then analyzed using the statistical analysis tool SPSS.the results show that the Variables in consumer confidence (X1) has a value of 0,163 with the level of sig.Content 0,141 > 0,05 . That is, the variable of consumer confidence have a positive influence and significant impact on the loyalty of the customer. Variable brand image (X2) has a value of 0,163 with the level of sig.0,042>0,05. That is, the variables brand image has positive and significant influence on the loyalty of the customer (Y) while the variable customer satisfaction (X3) has a value of 0,572 with the level of sig.0,000 >0,05. It means that customer satisfaction has positive and significant effect on loyalty customer Chatime places ciputra semarang.
\end{abstract}

Keywords: consumer trust, brand image, customer satisfaction, customer loyalty 


\section{PENDAHULUAN}

Persaingan komersial yang semakin ketat membuat konsumen menghadapi banyaknya produk yang ditawarkan. Dalam persaingan bisnis saat ini, perusahaan harus mengembangkan strategi untuk mengembangkan produk yang dapat memperoleh loyalitas dari pelanggan. Loyalitas adalah komitmen pembelian jangka panjang untuk suatu merek, toko, atau pemasok (Tjiptono 2000). Salah satu yang bisa meningkatkan loyalitas costumer adalah kepercayaan pelanggan.

Kepercayaan pelanggan adalah kepercayaan pelanggan terhadap produk, layanan, atau lokasi tertentu. Faktor lainya adalah citra merek itu sendiri yang juga berperan penting dalam meningkatkan loyalitas konsumen. Setiadi dalam (Rimiyati \& Widodo (2014) mendefinisikan brand image atau citra merek sebagai representasi dari semua pandangan tentang merek, pandangan tersebut dibentuk oleh pengalaman dan informasi tentang merek. Selain untuk mendapatkan kepercayaan dan citra merek yang baik, kepuasan customer terhadap produk atau jasa juga menjadi faktor yang dapat mendorong loyalitas costumer. Menurut definisi (Kotler dan Keller (2009) dalam (Rimiyati and Widodo 2014), kepuasan adalah perasaan yang diperoleh dengan membandingkan kinerja dengan produk, atau dengan mengungkapkan hasil bahagia atau mengecewakan dengan harapan.

Citra merek (Brand Image) dapat diartikan seperangkat ingatan yang ada di benak konsumen mengenai sebuah merek, baik itu positif maupun negatif. Citra yang positif tentunya dapat memberikan manfaat bagi produsen untuk lebih dikenal oleh konsumen. Dengan kata lain, konsumen akan menentukan pilihannya untuk membeli produk yang mempunyai citra yang baik. Begitu pula sebaliknya, jika citra merek negatif, konsumen cenderung mempertimbangkan lebih jauh lagi ketika akan membeli produk (Mamang dan Sopiah (2013:132) Semakin baik citra merek suatu produk, maka akan semakin tinggi keputusan konsumen dalam melakukan pembelian produk tersebut. 
Sedangkan kepuasan konsumen adalah tingkat perasaan konsumen setelah membandingkan antara apa yang diterima dengan harapannya terhadap suatu produk (Umar (2005) . Seorang pelanggan yang puas tentunya akan membawa keuntungan bagi produsen, karena akan dapat menumbuhkan loyalitas seorang konsumen. Menurut (Kotler dan Keller (2012) , kepuasan konsumen adalah perasaan senang atau kecewa seseorang yang muncul setelah membandingkan kinerja (hasil) produk yang dipikirkan terhadap kinerja yang diharapkan.

Bisnis kuliner yang berkembang pesat adalah bubble tea. Bubble tea sendiri memiliki beragam merek produk ternama. Salah satu merek bubble tea adalah cha time. Merek waktu minum teh ini berasal dari Taiwan dan bergerak di industri makanan dan minuman. Sejak berdiri pada tahun 2005, terdapat lebih dari 1.000 gerai di seluruh dunia, termasuk Indonesia. Ada kurang lebih 210 gerai di seluruh Indonesia (Bella 2019). Salah satu cabang Cha Time adalah Cha Time yang berlokasi di mall Ciputra, dimana berbagai produk teh seperti teh oolong, teh hijau, teh hitam, teh panggang, genmaicha, dll.

Banyak peneliti terdahulu yang membahas tentang variabel kepercayaan konsumen, citra merek, kepuasan konsumen dan loyalitas costumer diantaranya terdapat beberapa kontroversi antara peneliti satu dengan peneliti lainya. Penelitian yang dilakukan oleh (Yana et al. (2015) menunjukkan Citra Merek berpengaruh signifikan terhadap Kepuasan Pelanggan sementara penelitian yang dilakukan oleh (Haryantini 2019) menyatakan bahwa Citra Merek dan promosi tidak berpengaruh secara simultan terhadap variabel loyalitas. Konsumen selalu menilai suatu layanan yang diterima dibandingkan dengan apa yang diharapkan atau diinginkan (Parasuraman dalam (Hidayat (2009)). Namun menurut (Hidayat (2009)) kepuasan konsumen juga harus disertai dengan loyalitas konsumen, kepuasan konsumen berkaitan dengan apa yang diungkapkan oleh konsumen tentang persepsi dan harapannya terhadap layanan yang diperoleh. Sementara loyalitas berkaitan dengan 
apa yang dilakukan konsumen setelah berinteraksi dalam proses layanan. Konsep ini menyiratkan bahwa kepuasan konsumen saja tidaklah cukup, karena puas atau tidak puas hanyalah salah satu bentuk emosi. Disamping itu, loyalitas konsumen juga tidak kalah relevannya untuk dianalisis sebab sikap loyal konsumen akan timbul setelah konsumen Penelitian ini dilakukan di Bank BNI Cabang Manado. Alasan merasakan puas atau tidak puas terhadap layanan yang diterimanya (Tjiptono dan Chandra 2005:386). Berdasarkan uraian diatas, maka penelitian ini bertujuan untuk meneliti Itensitas kepercayaan konsumen, citra merek dan kapuasan konsumen terhadap loyalitas costumer Chatime dipusat perbelanjaan Mall Ciputra.

\section{TINJAUAN PUSTAKA}

\section{Kepercayaan Konsumen}

Menurut (Mowen dan Minor (2013:201) adalah kepercayaan konsumen sebagai semua pengetahuan yang dimiliki oleh konsumen dan semua kesimpulan yang oleh konsumen tentang objek, atribut, dan manfaatnya.

Menururt (Ba dan Pavlou (2002:122) mendefinisikan kepercayaan sebagai penilaian hubungan sesorang dengan orang lain yang akan melakukan transaksi tertentu sesuai dengan harapan dalam sebuah lingkungan yang penuh ketidakpastian.

Menurut (Firdayanti 2006) kepercayaan konsumen merupakan persepsi dari sudut pandang konsumen akan keandalan penjual dalam pengalaman dan terpenuhinya harapan dan kepuasan konsumen.

Indikator Kepercayaan Konsumen menurut ((Nuraini 2016) adalah Kejujuran penjual dalam bertransaksi., tanggungjawab penjual kepada pembeli., kepercayaan bahwa perusahaan memiliki reputasi yang baik

Hasil penelitian terdahulu menurut (Syaifulah (2018) menunjukan kepercayaan konsumen posifit signifikan memprediksi terhadap loyalitas customer. Sejalan dengan 
penelitian yang dilakukan oleh (Segara (2018) Kepercayaan konsumen berpengaruh secara positif dan signifikan terhadap loyalitas customer

\section{Citra Merek}

Menurut (Wijaya, Sasongko, and Wahyuni 2014) produk dengan brand image terbaik akan memungkinkan perusahaan mendapatkan keuntungan dari promosi, sehingga menjadi kekuatan bagi perusahaan untuk bersaing dalam bisnisnya. Hubungan antara citra merek dan keputusan pembelian konsumen dapat digunakan.

Menurut (Setiadi (2003) berpendapat bahwa Citra Merk mengacu pada skema memori akan sebuah merek, yang berisikan ingerpretasi konsumen atas atribuy, kelebihan, penggunaan, situasi, para pengguna, dan karateristik pemasar atau karateristik pembuat dari produk tersebut.

Menurut (Rangkuti (2009:44) indikator-indikator citra merek adalah Recognition (Pengenalan), Reputation (Reputasi), Affinity (Daya tarik), Loyality (kesetiaan).

Hasil penelitian terdahulu menunjukan menurut (Apriyani (2013), terdapat pengaruh yang signifikan antara citra merk terhadap loyalitas customer. Sejalan dengan penelitian yang dilakukan (Hengestu and Iskandar 2017) citra merk berpengaruh positif dan signifikan terhadap loyalitas customer.

\section{Kepuasan Konsumen}

Menurut (Daryanto \& Setiyobudi (2014), kepuasan konsumen menggunakan suatu produk, dimana harapan dan kebutuhan konsumen yang menggunakannya terpenuhi.

Menurut (Solomon and (2011) menyebutkan bahwa kepuasan konsumen adalah suatu perasaan keseluruhan konsumen mengenai produk atau jasa yang telah dibeli oleh konsumen.

Menurut (Djaslim Saladin (2003) pengertian kepuasan pelanggan adalah perasaan senang atau kecewa seseorang yang berasal dari perbandingan antara kesannya 
terhadap kinerja hasil suatu produk dan harapan-harapannya.

Adapun indikator kepuasan pelanggan menurut (Irawan (2008)), yaitu : Perasaan puas (dalam arti puas akan produk dan pelayanannya) Yaitu ungkapan perasaan puas atau tidak puas dari pelanggan saat menerima pelayanan yang baik dan produk yang berkualitas dari perusahaan., Selalu membeli produk Yaitu pelanggan akan tetap memakai dan terus membeli suatu produk apabila tercapainya harapan yang mereka inginkan., Akan merekomendasikan kepada orang lain Yaitu pelanggan yang merasa puas setelah memakai suatu produk atau jasa akan menceritakannya kepada orang lain serta mampu menciptakan pelanggan baru bagi suatu perusahaan., Terpenuhinya harapan pelanggan setelah membeli produk Yaitu sesuai atau tidaknya kualitas suatu produk atau jasa pasca pembelian suatu produk dengan harapan yang diinginkan pelanggan.

Semakin tinggi nilai kepuasan konsumen maka akan semakin tinggi pula loyalitas konsumen, sebaliknya jika semakin rendah tingkat kepuasan konsumen maka semakin rendah loyalitas konsumennya.

Hasil penelitian menurut (Pratama 2015) menunjukan hubungan antara kepuasan konsumen signifikan berpengaruh terhadap loyalitas customer. Sejalan dengan penelitian yang dilakukan oleh (Amalina 2010) mengatakan bahwa adanya hubungan yang signifikan antara kepuasan konsumen dengan loyalitas pelanggan. Hasil perhitungan parsial menunjukan adanya hubungan positif yang signifikan antara kepuasan konsumen terhadap loyalitas customer

\section{Loyalitas Konsumen}

Menurut (Oliver (2010)) loyalitas adalah komitmen jangka panjang pelanggan untuk memesan ulang atau secara konsisten membeli kembali produk atau layanan yang dipilih di masa depan, bahkan jika pengaruh keadaan dan upaya pemasaran dapat menyebabkan perubahan perilaku.

Menurut (Sutisna (2003:41))mendefinisikan loyalitas adalah sikap menyenangi 52 
terhadap suatu merk yang dipresentasikan dalam pembelian yang konsisten terhadap merk itu sepanjang waktu.

Menurut (Aswan 2015) loyalitas merupakan proses yang melibatkan pikiran dan emosi antara pelanggan dengan perushaan yang tidak dapat diukur dan dikelola, karena pikiran dan emosi pelanggan yang satu dengan yang lain berbeda sehingga akan sulit untuk diukur atau dilambangkan.

Indikator-indikator Loyalitas Menurut (Bastian (2014)) adalah perilaku tindakan, pengukuran biaya pengganti, pengukuran kepuasan, pengukuran kesukaan merk, dan pengukuran komitmen.

\section{METODE PENELITIAN}

Jenis penelitian menggunakan metode deskripsi kuantitatif. Menggunakan kuesioner untuk mengumpulkan data terkait variabel kepercayaan konsumen (XI), variabel citra merek (X2), variabel kepuasan konsumen (X3), dan variabel loyalitas costumer $(Y)$

Penelitian ini di lakukan di mall ciputra Semarang penelitian ini dilaksanakan pada bulan Maret 2021. Populasi dalam penelitian ini adalah Seluruh pelanggan Chatime di Kota Semarang.

Dalam penelitian ini Teknik yang digunakan dalam menentukan sampel adalah rumus isaac dan michael dimana untuk menghitung sample dan populasinya tidak diketahui secara pasti. sehingga responden dalam penelitian ini adalah 99 orang. Angket atau kuesioner diukur dengan menggunakan skala likert 1 s/d 5. Data yang di peroleh dianalis dengan menggunakan alat analisis stastik SPSS. 


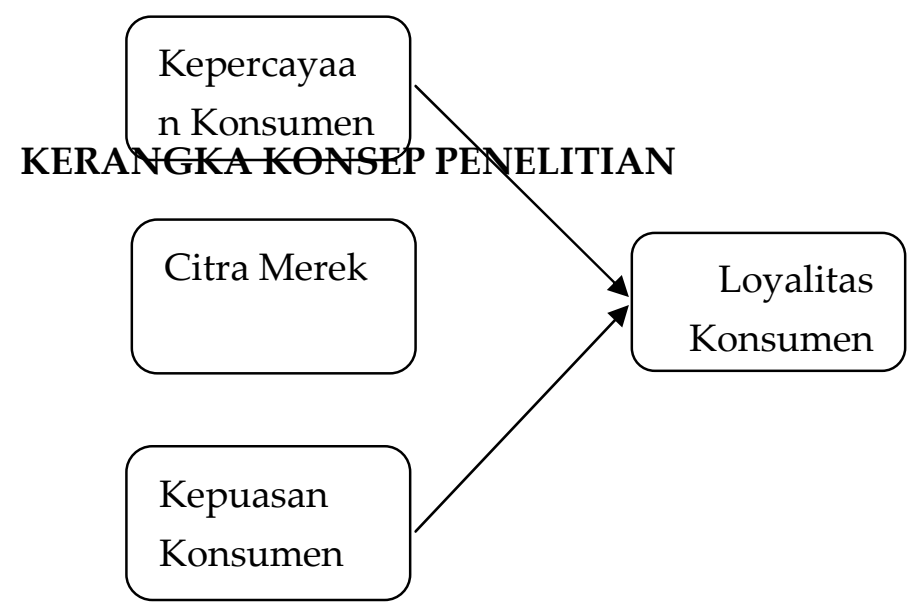

\section{HIPOTESIS PENELITIAN}

H1 : Kepercayaan Konsumen berpengaruh terhadap loyalitas pelanggan

H2 : terdapat korelasi positif yang signifikan antara citra merek dengan loyalitas konsumen

H3 : kepuasan konsumen terbukti memiliki pengaruh positif dan langsung yang signifikan terhadap loyalitas konsumen

\section{HASIL PENELITIAN DAN PEMBAHASAN}

Tabel 1 Hasil Uji Regresi Linier Berganda

\begin{tabular}{|c|c|c|c|c|c|c|}
\hline \multicolumn{7}{|c|}{ Coefficients $^{a}$} \\
\hline \multirow{2}{*}{\multicolumn{2}{|c|}{ Model }} & \multicolumn{2}{|c|}{$\begin{array}{l}\text { Unstandardized } \\
\text { Coefficients }\end{array}$} & \multirow{2}{*}{$\begin{array}{c}\text { Standardized } \\
\text { Coefficients }\end{array}$} & \multirow[t]{2}{*}{$\mathrm{t}$} & \multirow[t]{2}{*}{ Sig. } \\
\hline & & B & Std. Error & & & \\
\hline \multirow[t]{4}{*}{1} & (Constant) &,- 125 & 1,302 & &,- 096 & ,924 \\
\hline & $\begin{array}{l}\text { Kepercayaan } \\
\text { konsumen }\end{array}$ & ,298 & 141 & , 163 & 2,109 & ,038 \\
\hline & Citra merek & ,260 & ,126 & ,192 & 2,057 &, 042 \\
\hline & $\begin{array}{l}\text { Kepuasan } \\
\text { konsumen }\end{array}$ & ,589 & ,093 & ,572 & 6,346 & ,000 \\
\hline
\end{tabular}

1. Dependent Variable: Y1 
Berdasarkan hasil analisis regresi, Variabel kepercayaan kosumen (X1) memiliki nilai 0,163 dengan taraf sig.0,141 > 0,05. Artinya, variabel kepercayaan konsumen memiliki pengaruh positif terhadap loyalitas costumer dan jika semakin baik kepercayaan konsumen maka semakin meningkat loyalitas costumer pembelian Chatime dimall ciputra semarang. Variabel citra merek (X2) memiliki nilai 0,163 dengan taraf sig.0,042 > 0,05. Artinya, variabel citra merek memiliki pengaruh positif terhadap loyalitas costumer $(\mathrm{Y})$ sedangkan variabel kepuasan konsumen $(\mathrm{X} 3)$ memiliki nilai 0,572 dengan taraf sig.0,000 $>0,05$. Artinya kepuasan konsumen berpengaruh terhadap loyalitas costumer.

\section{Intensitas kepercayaan konsumen terhadap loyalitas costumer di Mall Ciputra}

Dari hasil penelitian ini menunjukan bahwa kepercayaan konsumen memiliki pengaruh positif terhadap loyalitas customer dan jika semakin baik kepercayaan konsumen maka semakin meningkat loyalitas customer pembelian Chatime dimall ciputra semarang. Seperti penelitian Chu (2003) yang menyatakan bahwa kepercayaan pelanggan sebagai anggota club hause atas jasa yang di berikan akan terdampak pada kepuasan dan loyalitas, secara logika jika ada kepercayaan dalam suatu hubungan maka kedua belah pihak akan saling menjaga sehingga akan memberikan apa yang seharusnya diberikan dan menerima apa yang seharusnya di terima

\section{Intensitas Citra merek terhadap loyalitas costumer di Mall Ciputra}

Dari hasil uji, serta hipotesis penelitian citra merek menunjukan taraf signifikan. Artinya, variabel citra merek memiliki pengaruh positif terhadap loyalitsa customer. Semakin baik citra merek perusahaan dalam memasarkan produk maka akan meningkatkan loyalitas customer. menurut Setiadi (2003) brand image adalah citra dari keseluruhan persepsi terhadap merek yang di bentuk dari informasi dan pengalaman masa lalu terhadap merek itu berhubungan dengan sikap yang berupa keyakinan dan preferensi terhadap suatu merek.

\section{Intensitas kepuasan konsumen terhadap loyalitas costumer di Mall Ciputra}


dari hasil uji memiliki nilai dengan taraf yang signifikan artinya kepuasan konsumen berpengaruh terhadap loyalitas customer menurut kotler (2005) kepuasan konsumen diartikan sebagai suatu keadaan dimana harapan konsumen terhadap suatu produk sesuai dengan kenyataan yang di terima oleh konsumen. jika produk itu jauh di bawah harapan, konsumen akan kecewa sebaliknya jika produk tersebut memenuhi harapan, konsumen akan puas.

\section{KESIMPULAN}

Berdasarkan hasil analisis data serta pembahasan mengenai kepercayaan konsumen, citra merk, kepuasan konsumen terhadap loyalitas customer maka diperoleh beberapa kesimpulan bahwa kepercayaan konsumen, citra merek dan kepuasan konsumen berpengaruh postitif terhadap loyalitas costumer Chatime di mall ciputra kota semarang yang dipengaruhi oleh variable kepercayaan konsumen, citra merek dan kepuasan konsumen. Dalam meningkatkan loyalitas konsumen Chatime di Mall Ciputra adalah dengan meningkatkan kepercayaan konsumen seperti mengedepankan nilai kejujuran yang ditanamkan oleh karyawan chatime maupun bahan bahan yang digunakan, memempertahakan citra merk dengan tetap menjaga baik nama perusahaan yang telah dibangun sejak lama dan mempertahankan kepuasan konsumen dengan meningkatkan kesigapan dalam membantu pelanggan, lebih proaktif dalam memberikan informasi dan berusaha memenuhi kebutuhan pelanggan dengan begitu akan meningkatkan kepuasan pelanggan.

\section{DAFTAR PUSTAKA}

(Nuraini, 2009). 2016. “Diajukan Sebagai Salah Satu Syarat Untuk Memperoleh Gelar Sarjana (STRATA 1)." (102):28.

(Tjiptono dan Chandra 2005:386). n.d. .“.Xdolwdv /D \dqdqdq Flwud Phuhn«.” 20. 
Amalina, Camelia Hanifah. 2010. "Hubungan Antara Kepuasan Konsumen Dan Kualitas Pelayanan Dengan Loyalitas Konsumen Pada Ritel Modern." 1-64.

Apriyani (2013). 2015. “Fakultas Ekonomi Dan Bisnis Universitas Udayana , Bali , Indonesia Fakultas Ekonomi Dan Bisnis Universitas Udayana, Bali, Indonesia ABSTRAK PENDAHULUAN Globalisasi Dapat Memberikan Suatu Peluang Maupun Ancaman Bagi Merek Yang Kompetitif Di Pasar Global.” 4(10):3237.

Aswan, 2013. 2015. “Consumer Loyalty ).” 17.

Ba dan Pavlou (2002:122). 2007. “Pengaruh Dimensi Kepercayaan (Trust) Terhadap Partisipasi Pelanggan E-Commerce (Studi Pada Pelanggan E-Commerce Di Indonesia)." Universitas Brawijaya 157.

Bastian (2014). 2018. "Analisis Pengaruh Citra Merek Dan Kepercayaan Merek Pada Loyalitas Merek Mie Sedap." Jounal Universitas Sanata Dharma 19-20.

Bella, Z. W. 2019. “Prediksi Kepuasan Pelanggan, Kualitas Layanan, Dan Kepercayaan Merek Terhadap Loyalitas Pelanggan Chatime." Jurnal Manajerial Dan Kewirausahaan I(2):126-32.

Daryanto \& Setiyobudi (2014). 2014. “BAB II TINJAUAN PUSTAKA A. Kepuasan

Konsumen 1. Pengertian Kepuasan Konsumen." (1992):16.

Djaslim Saladin (2003). 2019. “済無No Title No Title.” ISSN 2502-3632 (Online) ISSN 2356-0304 (Paper) Jurnal Online Internasional \& Nasional Vol. 7 No.1, Januari - Juni 2019 Universitas 17 Agustus 1945 Jakarta 53(9):2.

Firdayanti, (2021). 2006. “No Title.” (1994):16-37.

Haryantini, Haryantini. 2019. “Pengaruh Citra Merek Dan Promosi Terhadap Loyalitas

Pelanggan Go-Jek Di Stasiun Depok Jawa Barat." Jurnal Pemasaran Kompetitif 3(1):45. doi: 10.32493/jpkpk.v3i1.3604.

Hengestu, Nelsen, and Donant Alananto Iskandar. 2017. “Pelanggan Air Minum Dalam Kemasan." Jurnal Riset Manajemen Dan Bisnis 2(3):363-72.

Irawan (2008). 2013. “Kualitas Produk, Kepuasan Pelayanan Terhadap Tingkat 57 
Kepuasan." Journal of Chemical Information and Modeling 53(9):10.

Kotler dan Keller (2009). 2014. “Pengaruh Kualitas Layanan Dan Kualitas Produk Terhadap Kepuasan Pelanggan Dan Loyalitas Konsumen Restoran Happy Garden Surabaya." 2(1):1.

Kotler dan Keller (2012). 2016. “Pengaruh Kualitas Produk Terhadap Tingkat Kepuasan Konsumen Dan Loyalitas Konsumen." Jurnal Administrasi Bisnis (JAB)|Vol. 38 No. 1 September 2016 38(1):125-32.

Mamang dan Sopiah (2013:132). 2018. “DIPONEGORO JOURNAL OF SOCIAL AND POLITIC Tahun 2018, Hal. 1-8 Http://Ejournal- S1.Undip.Ac.Id/Index.Php/ Pengaruh Kualitas Produk, Harga Dan Citra Merek Terhadap Keputusan Pembelian Konsumen." Diponegoro Journal of Social and Politic 1-8.

Mowen dan Minor (2013:201). 2016. “Pengaruh Kepercayaan Dan Kepuasan Pelanggan Terhadap Loyalitas Pelanggan." BISNIS : Jurnal Bisnis Dan Manajemen Islam 3(1):1. doi: 10.21043/bisnis.v3i1.1463.

Oliver (2010). 2014. “Faktor-Faktor Yang Memengaruhi Loyalitas Pelanggan Pada Penerbangan Low Cost Carrier." Jurnal Manajemen Transportasi \& Logistik (JMTransLog) 1(2):128.

Pratama, Putra Bayu. 2015. “Pengaruh Kepuasan Pelanggan Terhadap Loyalitas Pada Penggunaan Produk Outdoor." Skripsi Universitas Muhammadiyah Surakarta 1-21.

Rangkuti (2009:44). 2004. “Bab II Kajian Pustaka , Kerangka Pemikiran Dan Hipotesis.” (i):30-31.

Rimiyati \& Widodo (2014). 2014. "Country of Origin, Brand Image." Jurnal Manajemen XVIII(03):365-80.

Rimiyati, Hasnah, and Catur Widodo. 2014. “Pengaruh Citra Merek, Kualitas Produk, Kepuasan Konsumen Terhadap Loyalitas Konsumen Merek Samsung Galaxy Series (Studi Pada Mahasiswa Universitas Muhammadiyah Yogyakarta)." Jurnal Manajemen Bisnis 5(2):223-34. 
Segara (2018). 2019. “No Title."

Setiadi (2003). 2019. "Pengaruh Citra Merek, Harga Dan Kualitas Produk Terhadap Keputusan Pembelian (Studi Kasus Pada Konsumen Mie Endess Di Bangkalan)." Jurnal Studi Manajemen Dan Bisnis 6(2):98. doi: 10.21107/jsmb.v6i2.6688.

Solomon, Kapoor dan, and (2011). n.d. “Ni Wayan Wina Premayani Pengaruh Kewajaran Harga ...." 1(2):143.

Sutisna (2003:41). 2013. “済無No Title No Title.” Journal of Chemical Information and Modeling 53(9):2.

Syaifulah (2018). 2018. "Pengaruh Kepercayaan Dan Komunikasi Terhadap Loyalitas Pelanggan Pada Pt Spectrum Lintas Service Di Kota Batam." Jurnal Ilmiah Manajemen Universitas Putera Batam 6(1):231201.

Tjiptono, Fandy. 2000. Manajemen Jasa. Yogyakarta: Andi Offset.

Umar (2005). 2018. "ANALISIS FAKTOR-FAKTOR YANG MEMPENGARUHI.”

Wijaya, Erwin Adi, Sasongko, and Sri Wahyuni. 2014. “PRODUK SMARTPHONE SAMSUNG GALAXY SERIES PADA MAHASISWA JURUSAN .... ( The Influence of Brand Image to Purchase Decision Series Smartphone Samsung Galaxy Science Students ... )."

Yana et al. (2015). 2018. “Terhadap Kepuasan Konsumen Menggunakan Shampo L' Oréal Di Kota Palu." 4(3):219-28. 